\title{
New Strategy and Innovative Projects at the National Biosurveillance Integration Center
}

\author{
Steven Bennett and Teresa Quitugua* \\ Homeland Security, Washington, DC, USA
}

\section{Objective}

Enhance knowledge of the vision, mission, strategic goals, and objectives of the National Biosurveillance Integration Center (NBIC). Learn about innovative biosurveillance projects ongoing in NBIC.

\section{Introduction}

For a number of years, the federal government has provided biosurveillance in various domains within different departments and agencies. Congress recognized the need for a means of integrating these separate information sources into a more useable resource by chartering NBIC within the Department of Homeland Security.

\section{Methods}

NBIC engaged the biosurveillance community within and beyond the federal government through a series of extensive discussions, workshops, and symposia to define a strategy for future development of integrated biosurveillance activities grounded in legislative and presidential direction. The NBIC Strategic Plan was extensively reviewed by the twelve federal Departments that comprise the National Biosurveillance Integration System (NBIS) as well as the White House Office of Management and Budget. The NBIC Strategic Plan is currently being revised for release of a public version. The NBIC also engaged partners in the development of projects designed to develop and test new approaches to biosurveillance.

\section{Results}

The NBIC Strategic Plan was delivered to Congress in August, 2012. The plan explains the Center's approach, why it is needed, and how it seeks to execute the mission of integrating national biosurveillance information to provide relevant and timely information that effectively supports decision making. Projects are underway involving text analyses of emergency medical system data, changes to poison control center data collection and analysis, and the application of machine learning to social media analyses. A sub-working group of the NBIS has been established to guide selection of future pilot project areas to address prioritized requirements for integrated biosurveillance.

\section{Conclusions}

NBIC has increased flexibility in its commitment to collaboration and coordination, engaged in bold new approaches, and is defining requirements that will encourage buy-in and support of the users across the levels of government and the private sector. With success in its mission, NBIC will support its partners' missions and provide relevant and timely information that effectively supports decision making.

\section{Keywords}

NBIC; NBIS; strategy

\section{References}

(1) Public Law 110-53, "Implementing Recommendations of the 9/11 Commission Act of 2007," August 2007. Accessed online at http://intelligence.senate.gov/laws/pl11053.pdf.

(2) The White House, National Strategy for Biosurveillance, July 2012. Accessed online at http://www.whitehouse.gov/sites/default/files/National Strategy for Biosurveillance July 2012.pdf.

(3) Institute of Medicine, "Information Sharing and Collaboration: Applications to Integrated Biosurveillance - Workshop Summary," November 2011.

(4) Government Accountability Office, Report on Biosurveillance: Developing a Collaboration Strategy is Essential to Fostering Interagency Data and Resource Sharing, GAO 10-171 (Washington, DC: GAO, 2009).

(5) U.S. Department of Health and Human Services. National Biosurveillance Strategy for Human Health. February 2010. Accessed online at http://www.cdc.gov/osels/pdf/NBSHH_V2_FINAL.PDF.

(6) U.S. Department of Health and Human Services. National Health Security Strategy, December 2009. Accessed online at http://www.phe.gov/preparedness/planning/authority/nhss/strategy/documents/nhss-final.pdf.

(7) U.S. Department of Health and Human Services. Implementation Plan for the National Health Security Strategy of the United States of America, May 2012. Accessed online at http://www.phe.gov/Preparedness/planning/authority/nhss/ip/Documents/nhss-ip.pdf.

(8) The White House, "Biodefense for the 21st Century," Homeland Security Presidential Directive 10, April 28, 2004. Accessed online at http://www.fas.org/irp/offdocs/nspd/hspd-10.html.

(9) The White House, "Defense of United States Agriculture and Food," Homeland Security Presidential Directive 9, January 30, 2004. Accessed online at http://www.aphis.usda.gov/animal_health/emergency_management/downloads/hspd-9.pdf.

\footnotetext{
*Teresa Quitugua

E-mail: teresa.quitugua@hq.dhs.gov
} 